\title{
A new regulatory DNA motif of the gamma subclass Proteobacteria: identification of the LexA protein binding site of the plant pathogen Xylella fastidiosa
}

\author{
Susana Campoy, ${ }^{1}$ Gerard Mazón, ${ }^{1}$ Antonio R. Fernández de Henestrosa, ${ }^{1}$ \\ Montserrat Llagostera, ${ }^{1,3}$ Patricia Brant Monteiro ${ }^{2}$ and Jordi Barbé ${ }^{1,3}$
}

Author for correspondence: Jordi Barbé. Tel: +34 93581 1837. Fax: +34 935812387. e-mail: jordi.barbe@uab.es

1 Department of Genetics and Microbiology, Universitat Autònoma de Barcelona, Bellaterra, 08193 Barcelona, Spain

2 Fundo de Defesa da Citricultura (Fundecitrus), 14807-040, VI. MelhadoC. P. 391, Araraquara, Sao Paulo, Brazil

3 Centre de Recerca en Sanitat Animal (CReSA), Universitat Autònoma de Barcelona-Institut de Recerca i Tecnologia Agroalimentària (UABIRTA), Bellaterra, 08193 Barcelona, Spain

\begin{abstract}
Escherichia coli LexA protein is the repressor of a gene network whose members are directly involved in the repair of damaged DNA and in the survival of bacterial cells until DNA lesions have been eliminated. The lexA gene is widely present in bacteria, although the sequences of only three LexAbinding sites are known: Gram-positive, alpha Proteobacteria and some members of gamma Proteobacteria represented by $E$. coli. Taking advantage of the fact that the genome sequence of the plant-pathogenic bacterium Xylella fastidiosa has been determined, its lexA gene has been cloned and overexpressed in $E$. coli to purify its product. After demonstration that $X$. fastidiosa lexA and recA genes are co-transcribed, gel mobility shift assays and directed mutagenesis experiments using the promoter of the lexA-recA transcriptional unit demonstrated that the $X$. fastidiosa LexA protein specifically binds the imperfect palindrome TTAGN ${ }_{6}$ TACTA. This is the first LexA binding sequence identified in the gamma Proteobacteria differing from the $E$. coli-like LexA box. Although a computational search has revealed the presence of TTAGN ${ }_{6}$ TACTA-like motifs upstream of $X$. fastidiosa genes other than lexA, $X$. fastidiosa LexA only binds the promoter of one of them, XF2313, encoding a putative DNA-modification methylase. Moreover, $X$. fastidiosa LexA protein does not bind any of the other genes whose homologues are regulated by the LexA repressor in E. coli (uvrA, uvrB, ssb, ruvAB, ftsK, dinG, recN and ybfE). RTPCR quantitative analysis has also demonstrated that lexA-recA and XF2313 genes, as well as the $X$. fastidiosa genes which are homologues to those of $E$. coli belonging to the LexA regulon, with the exception of ssb, are DNA damage-inducible in $X$. fastidiosa.
\end{abstract}

Keywords: DNA damage, gene expression, SOS system

\section{INTRODUCTION}

Bacteria have different pathways to repair DNA damage, the SOS system being one of the most important (Walker, 1984). In Escherichia coli, the SOS response has been widely studied, with at least 40 genes constituting this regulon (Fernandez de Henestrosa et al., 2000; Courcelle et al., 2001). The recA and lexA gene products control the expression of the E. coli SOS network to which both belong, LexA protein being the

Abbreviation: DIG, digoxigenin. negative regulator (Walker, 1984). It has been demonstrated that the RecA protein is converted into an active conformation after binding to single-stranded DNA regions generated by DNA damage-mediated inhibition of replication or by enzymic processing of broken DNA ends (Sassanfar \& Roberts, 1990). After activation, RecA promotes autocatalytic cleavage of LexA, inducing the SOS genes (Walker, 1984). E. coli LexA cleavage occurs in the $\mathrm{Ala}_{84}-\mathrm{Gly}_{85}$ bond and is mediated by its Ser $_{119}$ and Lys ${ }_{156}$ residues by a similar mechanism to that of serine proteases (Little, 1991; Luo et al., 2001). Once DNA damage has been repaired, RecA is no longer activated and the LexA protein level increases again, 
inhibiting expression of SOS genes. Recently, it has been suggested that the product of $\operatorname{dinI}$ is involved in the arrest of RecA protein activation (Voloshin et al., 2001). Likewise, it has also been shown that some E. coli genes are DNA damage-inducible in a lexA-independent pathway, suggesting that other regulatory pathways could be involved in the E. coli DNA damage mediated response (Courcelle et al., 2001; Khil \& CameriniOtero, 2002).

The E. coli LexA repressor specifically binds regions placed upstream of SOS genes. These LexA binding sites are imperfect 16-bp palindromes whose consensus sequence is CTGTN ${ }_{8}$ ACAG (Walker, 1984), which has been designated as the E. coli SOS box. The presence of a similar LexA regulon has been described in other bacterial groups, although the LexA-binding sequence is not conserved. Thus, the imperfect palindrome CGAACRNRYGTTYC and the GTTCN ${ }_{7}$ GTTC direct repeat are the LexA boxes of Gram-positive bacteria and the alpha subclass Proteobacteria, respectively (Winterling et al., 1998; Fernandez de Henestrosa et al., 1998; Tapias \& Barbé, 1999). While the recA gene has been found in all sequenced eubacterial genomes, lex $A$ appears to be absent in some of them. In this way, a lexA-like gene does not seem to be present in Aquifex aeolicus, Borrelia burgdorferi, Chlamydia pneumoniae, Mycoplasma pneumoniae, Campylobacter jejuni, Helicobacter pylori and Porphyromonas gingivalis. Moreover, and with the exception of the plant-pathogenic bacterium Xylella fastidiosa, all members of the gamma subclass Proteobacteria whose genome sequences have been published (E. coli, Pseudomonas aeruginosa, Haemophilus influenzae, Pasteurella multocida and Vibrio cholerae) present an E. coli-like LexA box upstream of the promoter genes belonging to the SOS system. Nevertheless, and despite the absence of this E. coli-like LexA box, a lexA homologue gene is present in the genome of $X$. fastidiosa (Simpson et al., 2000). This fact indicates that, unlike what happens in both Gram-positive and alpha subclass Proteobacteria (Winterling et al., 1998; Tapias \& Barbé, 1999), a significant heterogeneity exists in the very compact phylogenetic gamma subclass, with respect to the sequence of the control region of the common LexA regulon.

Differences among the LexA networks of several bacteria seems to be not only limited to the LexA box, but also to the regulation mechanism. So, whereas the E. coli LexA represses gene transcription by precluding RNA polymerase binding to the promoter region (Brent \& Ptashne, 1981; Little et al., 1981; Bertrand-Burggraf et al., 1987), Rhodobacter sphaeroides LexA interferes with the clearance process besides also being able to act as a transcriptional activator (Tapias et al., 2002). All together indicate that it is not suitable to postulate a general model to explain how the LexA regulon functions in the Domain Bacteria, but this aspect must be studied in each one of their several phylogenetic groups. Likewise, the number of evolutionary analyses of regulatory sequences as well as of the constitution of different gene networks in the several bacterial phyla is increasing (Eisen \& Hanawalt, 1999; Tan et al., 2001; Makarova et al., 2001; Panina et al., 2001; Rodionov et al., 2001; Roy et al., 2002). Nevertheless, and for this kind of studies to be carried out, a previous identification of new regulatory sequences, as well as of the genes which are under their control, is required.

In this context, and also to further characterize the differences existing among the LexA regulon of several groups of the gamma subclass Proteobacteria, the $X$. fastidiosa lexA gene has been cloned, overexpressed in E. coli and its product purified to determine the sequence to which it binds. Furthermore, the effect of DNA damage on the expression of $X$. fastidiosa genes whose homologues are under LexA regulation in E. coli has also been analysed.

\section{METHODS}

Bacterial strains, plasmids, oligonucleotides and DNA techniques. Bacterial strains and plasmids used in this work are listed in Table 1. E. coli and X. fastidiosa strains were grown at either $37^{\circ} \mathrm{C}$ or $29^{\circ} \mathrm{C}$ in LB or PW medium (Davis et al., 1981; Sambrook et al., 1992), respectively. Antibiotics were added to the cultures at reported concentrations (Sambrook et al., 1992). E. coli cells were transformed with plasmid DNA as described by Sambrook et al. (1992). All restriction enzymes, PCR oligonucleotide primers, T4 DNA ligase and polymerase, and the DIG DNA labelling and detection kit were from Roche. DNA from $X$. fastidiosa cells was extracted as described by Monteiro et al. (2001).

The synthetic oligonucleotide primers used for PCR amplification are listed in Table 2. To facilitate subcloning of some PCR-amplified DNA fragments, specific restriction sites were incorporated into the oligonucleotide primers. These restriction sites are shown in Table 2. Mutants in the X. fastidiosa lexA promoter were obtained by PCR mutagenesis using oligonucleotides carrying designed substitutions (Table 2). The DNA sequence of all PCR-mutagenized fragments was determined by the dideoxy method (Sanger et al., 1977) on an ALF Sequencer (Pharmacia Biotech). In all cases the entire nucleotide sequence was determined for both DNA strands.

Molecular cloning of the $X$. fastidosa lexA gene. The $X$. fastidiosa lexA gene was amplified from the total DNA of the $X$. fastidiosa CVC 9a5c strain using the LexAup and LexAdw oligonucleotide primers (Table 2) corresponding to nucleotides -273 to -252 and +706 to +726 , with respect to its proposed translational starting point (Simpson et al., 2000). The $999 \mathrm{bp}$ PCR fragment obtained was cloned into the pGEM-T vector giving plasmid pUA945. To confirm that no mutation was introduced during the amplification reaction, the sequence of the fragment was determined. pUA945 was used as a template in PCR amplifications with LexANdeI and LexABamHI primers (Table 2), and the fragment obtained was again cloned in pGEM-T. The putative ATG initial triplet of LexA is part of the NdeI restriction site of the LexANdeI primer which enables IPTG-mediated overexpression of the $X$. fastidiosa LexA protein. After digestion with $\mathrm{NdeI}$ and $B a m \mathrm{HI}$, the lexA gene was cloned downstream of the T7 promoter of the $\mathrm{pET} 15 \mathrm{~b}$ expression vector (Novagen) carrying a $\mathrm{N}$-terminal tag containing six histidine residues according to standard procedures (Sambrook et al., 1992), and the ligation mix was transformed into DH5 $\alpha$ competent cells. Once confirmed that no mutation had been introduced in the lex $A$ gene contained in the pUA973 plasmid by DNA sequencing, 
Table 1. Bacterial strains and plasmids used in this work

\begin{tabular}{|c|c|c|}
\hline Strain/plasmid & Relevant features & Source/reference \\
\hline \multicolumn{3}{|l|}{ Xylella fastidiosa } \\
\hline CVC 9a5c & Wild-type strain & Fundecitrus \\
\hline \multicolumn{3}{|l|}{ E. coli } \\
\hline DH5 $\alpha$ & $\begin{array}{l}\text { supE4 } \Delta l a c U 169 \text { ( } \phi 80 \text { lacZ } \Delta \mathrm{M} 15) \text { hsdR17 recA1 } \\
\text { endA1 gyrA96 thi-1 relA1 }\end{array}$ & Clontech \\
\hline BL21(DE3) & $\mathrm{F}^{-}$ompT hsd $S_{\mathrm{B}}\left(r_{\mathrm{B}}-r_{\mathrm{B}}\right) d c m$ gal $\lambda(\mathrm{DE} 3)$ & Clontech \\
\hline \multicolumn{3}{|l|}{ Plasmids } \\
\hline pGEM-T & PCR cloning vector, $\mathrm{Ap}^{\mathrm{R}}$ & Promega \\
\hline pET15b & $\begin{array}{l}\text { Overexpression vector carrying a } \mathrm{N} \text {-terminal tag } \\
\text { containing six histidine residues; } \mathrm{Km}^{\mathrm{R}}\end{array}$ & Novagen \\
\hline pUA945 & $\begin{array}{l}\text { pGEMT derivative carrying a } 999 \text { bp PCR } \\
\text { fragment containing the } X \text {. fastidiosa lexA gene } \\
\text { including its own promoter region }\end{array}$ & This work \\
\hline pUA973 & $\begin{array}{l}\text { pET15b derivative carrying a } 764 \text { bp NdeI-Bam HI } \\
\text { fragment containing the X. fastidiosa lexA gene }\end{array}$ & This work \\
\hline
\end{tabular}

this was transformed into the E. coli BL21(DE3) strain for overexpression of the LexA protein.

Purification of the $X$. fastidiosa LexA protein. His-tag fusion protein was purified by using the Talon Metal Affinity Resin Kit (Clontech) as described by the manufacturer. To carry out this, E. coli BL21(DE3) cells containing pUA973 were grown in $250 \mathrm{ml} \mathrm{LB}$ broth with shaking until $\mathrm{OD}_{550} 0 \cdot 8$. Protein expression was induced by adding $10 \mathrm{mM}$ IPTG to the culture, which was incubated at $37^{\circ} \mathrm{C}$ for an additional $3 \mathrm{~h}$. Cells were harvested by centrifugation at $5000 \mathrm{~g}$ for $10 \mathrm{~min}$ at $4{ }^{\circ} \mathrm{C}$, resuspended in $10 \mathrm{ml}$ washing solution $\left(50 \mathrm{mM} \mathrm{NaH}{ }_{2} \mathrm{PO}_{4}\right.$, $300 \mathrm{mM} \mathrm{NaCl}, \mathrm{pH} 7)$ to which protease inhibitor cocktail (Complete Mini, EDTA free; Roche) was added to the concentration indicated by the supplier. After sonication of the cells, the lysate was centrifuged at $14000 \mathrm{~g}$ for $20 \mathrm{~min}$, and the supernatant was collected. Metal Affinity Resin (Clontech; $2 \mathrm{ml}$ ), previously equilibrated with washing buffer, was added to the supernatant and the mix was agitated for $20 \mathrm{~min}$ at room temperature to allow binding of the tagged LexA protein to the resin. Afterwards, it was centrifuged and washed several times with washing buffer. The resin was then transferred to a gravity-flow column and washed again with $10 \mathrm{ml}$ washing buffer. Tagged LexA protein was eluted by adding $10 \mathrm{ml}$ elution buffer $\left(50 \mathrm{mM} \mathrm{NaH}_{2} \mathrm{PO}_{4}, 300 \mathrm{mM} \mathrm{NaCl}\right.$, $150 \mathrm{mM}$ imidazole) and the eluate was collected in $500 \mu \mathrm{l}$ fractions. To determine the fraction containing the majority of the tagged LexA protein, SDS-PAGE in $15 \%$ polyacrylamide gels was performed according to standard procedures (Laemmli, 1970). The selected fraction was more than $98 \%$ pure as determined by Coomassie blue staining as shown in Fig. 1.

Mobility shift assays. X. fastidiosa LexA-DNA complexes were detected by electrophoretic mobility shift assays using purified X. fastidiosa LexA protein (Fig. 1). DNA probes were prepared by PCR amplification using one of the primers labelled at its $5^{\prime}$ end with digoxigenin (DIG) (Table 2) and purifying each product in a $2-3 \%$ low-melting-point agarose gel depending on DNA size. DNA-protein reactions $(20 \mu \mathrm{l})$ typically containing $10 \mathrm{ng}$ DIG-labelled DNA probe and $40 \mathrm{ng}$ purified $X$. fastidiosa LexA protein were incubated in binding buffer: $10 \mathrm{mM}$ HEPES/NaOH (pH 8), $10 \mathrm{mM}$ Tris/HCl
(pH 8), $5 \%$ glycerol, $50 \mathrm{mM} \mathrm{KCl,} 1$ mM EDTA, 1 mM DTT, $2 \mu \mathrm{g}$ poly $(\mathrm{dG}-\mathrm{dC})$ and $50 \mu \mathrm{g} \mathrm{BSA} \mathrm{ml}$. After $30 \mathrm{~min}$ at $30^{\circ} \mathrm{C}$, the mixture was loaded onto a $5 \%$ non-denaturing Tris/glycine polyacrylamide gel (pre-run for $30 \mathrm{~min}$ at $10 \mathrm{~V} \mathrm{~cm}^{-1}$ in $25 \mathrm{mM}$ Tris/ $\mathrm{HCl}$ (pH 8.5), $250 \mathrm{mM}$ glycine, $1 \mathrm{mM}$ EDTA. DNAprotein complexes were separated at $150 \mathrm{~V}$ for $1 \mathrm{~h}$, followed by transfer to a Biodine B nylon membrane (Pall Gelman Laboratory). DIG-labelled DNA-protein complexes were detected by following the manufacturer's protocol (Roche). For the binding-competition experiments, a 300-fold molar excess of either specific or non-specific unlabelled competitor DNA was also included in the mixture. When used, the protein amount of crude extract of IPTG-induced E. coli BL21(DE3) cells carrying either the pUA973 plasmid or the pET15b vector alone added to the binding mixture was about 500 ng. Protein concentrations were determined as described by Bradford (1976). All mobility shift assays were repeated a minimum of three times to assure reproducibility of the results.

RT-PCR analysis of $\boldsymbol{X}$. fastidiosa gene expression. To determine the transcriptional organization of $X$. fastidiosa lex $A$ and $r e c A$ genes, reverse transcriptase (Roche) was used to generate cDNA by RT-PCR using total RNA from $X$. fastidiosa as a template and the pair of primers indicated in Table 2 and designed to amplify a PCR product of $355 \mathrm{bp}$ if the lex $A$ and $r e c A$ genes constituted a single transcription unit. Total RNA from $X$. fastidiosa was prepared with Trizol as described by the supplier (Gibco) and treated with RNase-free DNase I (Roche) to assure the absence of contaminating DNA. RNA concentration and its integrity were determined by $A_{260}$ measurements and $1 \%$ formaldehyde-agarose gel electrophoresis, respectively (Sambrook et al., 1992). In all RT-PCR experiments, the absence of contaminating DNA in RNA samples after RNase-free DNase I (Roche) treatment was confirmed by processing a duplicate of them in the same way but without reverse transcriptase addition.

Mitomycin C-mediated induction of several genes studied in this work was carried out by real-time quantitative RT-PCR analysis of total $X$. fastidiosa RNA with the LightCycler apparatus (Roche), using the LC-RNA master SYBR green I kit (Roche) and primers indicated in Table 2, following 
Table 2. Oligonucleotide primers used in this work

EMSA, electrophoretic mobility shift assay.

\begin{tabular}{|c|c|c|c|}
\hline Primer & Sequence $\left(5^{\prime}-3^{\prime}\right)^{*}$ & Posn $\dagger$ & Application \\
\hline LexAup & GCTCAGTGTGATGCATCCATT & -273 & Upper primer for cloning $X$. fastidiosa lexA gene \\
\hline LexAdw & CAGCTTAAACTGCCAAGGCA & +726 & Lower primer for cloning $X$. fastidiosa lexA gene \\
\hline LexANdeI & CATATGAGTTTGAGCGATATTCAG & +1 & Upper primer for cloning $X$. fastidiosa lex $A$ gene in the $\mathrm{pET} 15 \mathrm{~b}$ vector \\
\hline LexABamHI & GGATCCCAGCTTAAACTGCCAAGGCA & +726 & Lower primer for cloning $X$. fastidiosa lexA gene in the $\mathrm{pET} 15 \mathrm{~b}$ vector \\
\hline LexA + 92 & GTCTGCGAAGGAGAAACGCC & +92 & $\begin{array}{l}\text { Lower primer for cloning } X \text {. fastidiosa lexA promoter used as specific } \\
\text { competitor in EMSA assays }\end{array}$ \\
\hline LexA + 92dig & DIG-GTCTGCGAAGGAGAAACGCC & +92 & $\begin{array}{l}\text { Lower primer used to obtain wild-type and mutagenized lexA probes } \\
\text { (digoxigenin } 5^{\prime} \text {-end labelled) }\end{array}$ \\
\hline LexA-87 & GCTGGATCTGGCAGTATGG & -87 & Upper primer to obtain the LexA2 fragment \\
\hline LexA-25 & GTGCTTATTAGTAATAATAC & -25 & Upper primer to obtain the LexA3 fragment \\
\hline LexA-10 & AATACTAATTATGAGTTTG & -10 & Upper primer to obtain the LexA4 fragment \\
\hline Mut1 & GTGCTTAaccaTAATAATACTAATTATG & -25 & $\begin{array}{l}\text { Upper primer to obtain the mutagenized probe containing a change on the } \\
\text { left motif of the proposed palindrome }\end{array}$ \\
\hline Mut2 & GTGCTTATTAGTAATAATAaaggTTATG & -25 & $\begin{array}{l}\text { Upper primer to obtain the mutagenized probe containing a change on the } \\
\text { right motif of the proposed palindrome }\end{array}$ \\
\hline Mut + ggg & GTGCTTATTAGTgggAATAATACTAATTATG & -25 & $\begin{array}{l}\text { Upper primer to obtain the mutagenized probe containing an insertion in } \\
\text { the middle of the proposed palindrome }\end{array}$ \\
\hline LexA1 & GTGCTTㄷTAGTAATAATACTAATTATGAG & -25 & Upper primer to obtain single mutants in lexA promoter \\
\hline LexA2 & GTGCTTĀâTAGTAATAATACTAATTATGAG & -25 & Upper primer to obtain single mutants in lex $A$ promoter \\
\hline LexA3 & GTGCTTATㅆAGTAATAATACTAATTATGAG & -25 & Upper primer to obtain single mutants in lex $A$ promoter \\
\hline LexA4 & GTGCTTATT̄드AATAATACTAATTATGAG & -25 & Upper primer to obtain single mutants in lex $A$ promoter \\
\hline LexA5 & GTGCTTATTAäTAATAATACTAATTATGAG & -25 & Upper primer to obtain single mutants in lex $A$ promoter \\
\hline LexA6 & GTGCTTATTAG도ATAATACTAATTATGAG & -25 & Upper primer to obtain single mutants in lex $A$ promoter \\
\hline LexA7 & GTGCTTATTAGTㅗATAATACTAATTATGAG & -25 & Upper primer to obtain single mutants in lex $A$ promoter \\
\hline LexA8 & GTGCTTATTAGTAçAATACTAATTATGAG & -25 & Upper primer to obtain single mutants in lex $A$ promoter \\
\hline LexA9 & GTGCTTATTAGTAĀcAATACTAATTATGAG & -25 & Upper primer to obtain single mutants in lex $A$ promoter \\
\hline LexA10 & GTGCTTATTAGTAAT스ACACTATTATGAG & -25 & Upper primer to obtain single mutants in $\operatorname{lex} A$ promoter \\
\hline LexA11 & GTGCTTATTAGTAATĀctACTAATTATGAG & -25 & Upper primer to obtain single mutants in lex $A$ promoter \\
\hline LexA12 & GTGCTTATTAGTAATAĀcACTAATTATGAG & -25 & Upper primer to obtain single mutants in lex $A$ promoter \\
\hline LexA13 & 5'-GTGCTTATTAGTAATÄAT듯ATATATGAG & -25 & Upper primer to obtain single mutants in lex $A$ promoter \\
\hline LexA14 & 5'-GTGCTTATTAGTAATAATAäTAATTATGAG & -25 & Upper primer to obtain single mutants in lex $A$ promoter \\
\hline
\end{tabular}


Table 2 (cont.)

\begin{tabular}{|c|c|c|c|}
\hline Primer & Sequence $\left(5^{\prime}-3^{\prime}\right)^{*}$ & Posn & Application \\
\hline LexA15 & GTGCTTATTAGTAATAATACaAATTATGAGATATTCAGC & -25 & Upper primer to obtain single mutants in $\operatorname{lex} A$ promoter \\
\hline LexA16 & GTGCTTATTAGTAATAATACTgATTATGAGATATTCAGC & -25 & Upper primer to obtain single mutants in $\operatorname{lex} A$ promoter \\
\hline LexA17 & GTGCTTATTAGTAATAATACTĀgTTATGAGATATTCAGC & -25 & Upper primer to obtain single mutants in $\operatorname{lex} A$ promoter \\
\hline LexA18 & 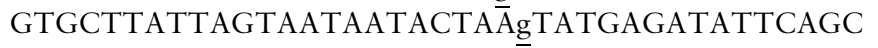 & -25 & Upper primer to obtain single mutants in lexA promoter \\
\hline RecAup & GACCGGATTCGTTTGCTACC & $+522 \ddagger$ & $\begin{array}{l}\text { Upper primer for cloning the upstream region of } X \text {. fastidiosa recA gene, } \\
\text { to analyse transcriptional organization of } r e c A \text { and } \operatorname{lex} A \text { genes, and for } \\
\text { mRNA quantification assays }\end{array}$ \\
\hline RecAdw & CCCTTGCCGAACTAATCTGG & $+877 \ddagger$ & $\begin{array}{l}\text { Lower primer for cloning the upstream region of } X \text {. fastidiosa recA gene, } \\
\text { to analyse transcriptional organization of } \operatorname{rec} A \text { and } \operatorname{lexA} \text { genes, and for } \\
\text { mRNA quantification assays }\end{array}$ \\
\hline RecAdw-dig & dig-CCCTTGCCGAACTAATCTGG & $+877 \neq$ & $\begin{array}{l}\text { Lower primer used to obtain recA probes for EMSA assays (digoxigenin } \\
5^{\prime} \text {-end labelled) }\end{array}$ \\
\hline UvrAup & GAATTCTGAACAACGCGATATTGC & -387 & Upper primer for cloning $X$. fastidiosa uvrA promoter for EMSA assays \\
\hline UvrAdw & GGATCCGATTCTTAAGATTGTGTG & +53 & Lower primer for cloning $X$. fastidiosa $u v r A$ promoter for EMSA assays \\
\hline UvrBup & GAATTCTCGCTAAGCAGGTGTTGC & -407 & Upper primer for cloning $X$. fastidiosa uvrB promoter for EMSA assays \\
\hline UvrBdw & GGATCCCTGCTTCTCAGTGAGATG & +39 & Lower primer for cloning $X$. fastidiosa $u v r B$ promoter for EMSA assays \\
\hline Ssbup & GAATTCCAGCTAACATCGTTAGC & -301 & Upper primer for cloning $X$. fastidiosa ssb promoter for EMSA assays \\
\hline Ssbdw & GGATCCGATCGTTCAAGCGGTTAC & +76 & Lower primer for cloning $X$. fastidiosa ssb promoter for EMSA assays \\
\hline DinGup & GAACTCGTCACCAATGATCC & -394 & Upper primer for cloning $X$. fastidiosa $\operatorname{din} G$ promoter for EMSA assays \\
\hline DinGdw & GTTGTTCAAAAATCTCGCC & +75 & Lower primer for cloning $X$. fastidiosa $\operatorname{din} G$ promoter for EMSA assays \\
\hline RecNup & ACACGTAGCCGACGAATATC & -420 & Upper primer for cloning $X$. fastidiosa recN promoter for EMSA assays \\
\hline RecNdw & GATGTTACGGACAACAGCG & +49 & Lower primer for cloning $X$. fastidiosa recN promoter for EMSA assays \\
\hline RuvAup & CCGCCATGTCTACCATGC & -526 & Upper primer for cloning $X$. fastidiosa ruvA promoter for EMSA assays \\
\hline RuvAdw & CTCСАCACACATCAACCACG & +69 & Lower primer for cloning $X$. fastidiosa ruvA promoter for EMSA assays \\
\hline YigNup & CGTTATGCCGAATACTTTGC & -466 & Upper primer for cloning $X$. fastidiosa yigN promoter for EMSA assays \\
\hline YigNdw & GTCATGAAGCACCATTGAGC & +66 & Lower primer for cloning $X$. fastidiosa $y i g N$ promoter for EMSA assays \\
\hline Ftskup & TACTGGTTGAAGGTTTGC & -451 & Upper primer for cloning $X$. fastidiosa ftsK promoter for EMSA assays \\
\hline FstKdw & GCGATCATGATCAACACC & +58 & Lower primer for cloning $X$. fastidiosa $f t s K$ promoter for EMSA assays \\
\hline XF2313up & TAACCAGATCATTGCCGTGG & -303 & Upper primer for cloning X. fastidiosa XF2313 promoter for EMSA assays \\
\hline XF2313dw & AAGCAGCCGCAGTGCGTCGC & +59 & Lower primer for cloning $X$. fastidiosa XF2313 promoter for EMSA assays \\
\hline XF1822up & CCAACAGTGCATATGTTGGC & +51 & Upper primer for cloning X. fastidiosa XF1822 promoter for EMSA assays \\
\hline XF1822dw & ATTCTGCTATTACGGTAGCC & -549 & Lower primer for cloning $X$. fastidiosa XF1822 promoter for EMSA assays \\
\hline XF1614up & TCTTCTAGTGGATTCTGTCC & -556 & Upper primer for cloning X. fastidiosa XF1614 promoter for EMSA assays \\
\hline XF1614dw & GCTCCAGTGCTTATAATCGG & -253 & Lower primer for cloning $X$. fastidiosa XF1614 promoter for EMSA assays \\
\hline
\end{tabular}


Table 2 (cont.)

\begin{tabular}{|c|c|c|c|}
\hline Primer & Sequence $\left(5^{\prime}-3^{\prime}\right) *$ & Posn $\dagger$ & Application \\
\hline XF1417dw & AAAGGCCCTGTTCCAGCCTC & +180 & Lower primer for cloning $X$. fastidiosa XF1417 promoter for EMSA assays \\
\hline XF1271up & GTTCGATGTCGGAGGACGTC & -317 & Upper primer for cloning $X$. fastidiosa XF1271 promoter for EMSA assays \\
\hline XF2297up & CTCTACGTAGTTGTACGC & -321 & Upper primer for cloning X. fastidiosa XF2297 promoter for EMSA assays \\
\hline XF2297dw & CGCCAATCAGTTAAACAC & +84 & Lower primer for cloning X. fastidiosa XF2297 promoter for EMSA assays \\
\hline XF2313/1 & TTGTTGCGTCATCTGCGTCG & +5 & $\begin{array}{l}\text { Upper primer for cloning an internal region of X. fastidiosa XF2313 gene } \\
\text { for mRNA quantification assays }\end{array}$ \\
\hline UvrA1 & CGCGGACACACAATCTTAAG & +29 & $\begin{array}{l}\text { Upper primer for cloning an internal region of } X \text {. fastidiosa uvrA gene for } \\
\text { mRNA quantification assays }\end{array}$ \\
\hline UvrA3 & TGCGCTCACGTACCACAG & +425 & $\begin{array}{l}\text { Lower primer for cloning an internal region of } X \text {. fastidiosa uvrA gene for } \\
\text { mRNA quantification assays }\end{array}$ \\
\hline UvrB1 & TGAGCAGCGGCAATTGATCAG & +1 & $\begin{array}{l}\text { Upper primer for cloning an internal region of X. fastidiosa } u v r B \text { gene for } \\
\text { mRNA quantification assays }\end{array}$ \\
\hline UvrB2 & GTCTGACCGGTAAGCGGATC & +202 & $\begin{array}{l}\text { Lower primer for cloning an internal region of } X \text {. fastidiosa } u v r B \text { gene for } \\
\text { mRNA quantification assays }\end{array}$ \\
\hline $\mathrm{RecN} 1$ & CAACATCACGATACACCACCC & +204 & $\begin{array}{l}\text { Upper primer for cloning an internal region of } X \text {. fastidiosa recN gene for } \\
\text { mRNA quantification assays }\end{array}$ \\
\hline $\mathrm{RecN} 2$ & GATTCGCTCGGACATATCGC & +558 & $\begin{array}{l}\text { Lower primer for cloning an internal region of } X \text {. fastidiosa recN gene for } \\
\text { mRNA quantification assays }\end{array}$ \\
\hline Ssb1 & TGGCCCGTGGTATCAATAAG & +7 & $\begin{array}{l}\text { Upper primer for cloning an internal region of } X \text {. fastidiosa ssb gene for } \\
\text { mRNA quantification assays }\end{array}$ \\
\hline
\end{tabular}


Table 2 (cont.)

\begin{tabular}{|c|c|c|c|}
\hline Primer & Sequence $\left(5^{\prime}-3^{\prime}\right)^{*}$ & Posn $\dagger$ & Application \\
\hline YigN1 & GTTTGGATGAGCTGACTGCC & +204 & $\begin{array}{l}\text { Upper primer for cloning an internal region of } X \text {. fastidiosa yigN gene for } \\
\text { mRNA quantification assays }\end{array}$ \\
\hline YigN2 & AGACACCGTTGAGATCACCG & +518 & $\begin{array}{l}\text { Lower primer for cloning an internal region of } X \text {. fastidiosa yigN gene for } \\
\text { mRNA quantification assays }\end{array}$ \\
\hline FtsK1 & AGGCTGGTGCTTGGATTGCG & +81 & $\begin{array}{l}\text { Upper primer for cloning an internal region of } X \text {. fastidiosa } f t s K \text { gene for } \\
\text { mRNA quantification assays }\end{array}$ \\
\hline RuvA1 & CTCGTGGTTGATGTGTGTGG & +50 & $\begin{array}{l}\text { Upper primer for cloning an internal region of } X \text {. fastidiosa ruvA gene for } \\
\text { mRNA quantification assays }\end{array}$ \\
\hline RuvA2 & СТCAACTCCACCAGCATACG & +386 & $\begin{array}{l}\text { Lower primer for cloning an internal region of } X \text {. fastidiosa } r u v A \text { gene for } \\
\text { mRNA quantification assays }\end{array}$ \\
\hline Thr1 & TGCTCAAGCACAAACACC & +1059 & $\begin{array}{l}\text { Upper primer for cloning an internal region of X. fastidiosa threonine } \\
\text { synthase gene for mRNA quantification assays }\end{array}$ \\
\hline Thr2 & CTGAACCTCATTGTGCCC & +685 & $\begin{array}{l}\text { Lower primer for cloning an internal region of } X \text {. fastidiosa threonine } \\
\text { synthase gene for mRNA quantification assays }\end{array}$ \\
\hline rRNA1 & ACGCTAATACCGCATACGACC & $172439 \$$ & $\begin{array}{l}\text { Upper primer for cloning an internal region of X. fastidiosa } 16 \mathrm{~S} \text { rRNA } \\
\text { gene for mRNA quantification assays (used as control) }\end{array}$ \\
\hline rRNAdw2 & GAAGTTAGCCGGTGCTTATTC & $173003 \$$ & $\begin{array}{l}\text { Lower primer for cloning an internal region of } X \text {. fastidiosa } 16 \mathrm{~S} \text { rRNA } \\
\text { gene for mRNA quantification assays }\end{array}$ \\
\hline
\end{tabular}

* When present, added restriction sites are shown in italics and introduced nucleotide changes are shown in lower case and underlined.

†Position of $5^{\prime}$ end of the oligonucleotide with respect to the proposed translational starting point of each X. fastidiosa gene.

$\neq$ Position of $5^{\prime}$ end of the oligonucleotide with respect to the proposed translational starting point of X. fastidiosa lex $A$ gene.

\$Position of $5^{\prime}$ end of the oligonucleotide in X. fastidiosa genome. 


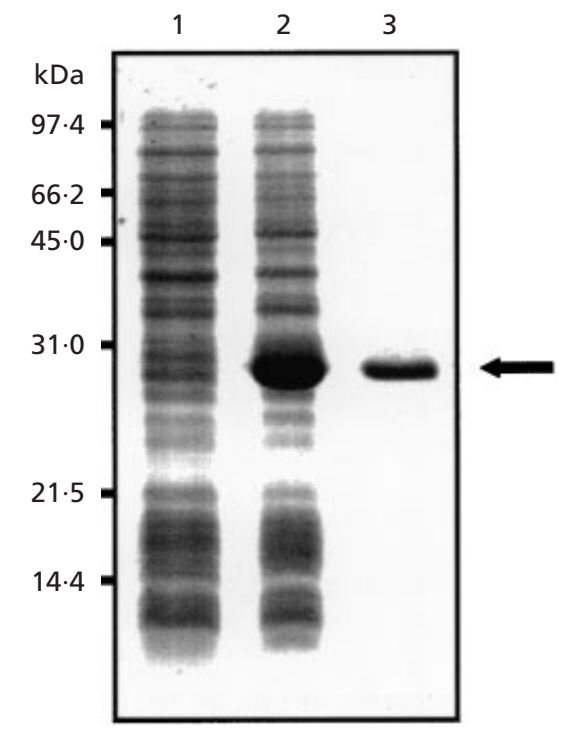

Fig. 1. Overproduction and purification of $X$. fastidiosa LexA in E. coli. Samples were analysed by SDS-PAGE ( $15 \%$ acrylamide). Lanes 1 and 2 contain crude extracts from $E$. coli BL21(DE3)/pUA973 cells in the absence or in the presence of IPTG, respectively. The purified His-tagged $X$. fastidiosa LexA protein after $\mathrm{Co}^{2+}$-affinity chromatography is shown in lane 3. The molecular masses of protein markers are indicated on the left side.

supplier's instructions. The concentration of total RNA of both treated and untreated cultures was adjusted to the same value. The amount of mRNA of each gene was determined by plotting it against a standard curve generated by the amplification of an internal fragment of the $X$. fastidiosa $16 \mathrm{~S}$ rRNA with the appropriate primers indicated in Table 2. In all determinations, the amount of mRNA of X. fastidiosa XF1375 and XF2223 genes, encoding tryptophan synthase and threonine synthase, respectively, was also determined. These two genes were used as negative controls because their expression is not DNA-damage-inducible in E. coli (Courcelle et al., 2001).

\section{RESULTS AND DISCUSSION}

\section{$X$. fastidiosa LexA protein specifically binds to its own promoter}

Gel mobility shift assays with the purified X. fastidiosa LexA were used to determine the binding ability of this protein to its own promoter. Addition of increasing concentrations of LexA to a fragment extending from -273 to +92 of the X. fastidiosa lexA gene promoter (with respect to its proposed translational start point) produces one retardation band whose intensity is directly related to the amount of protein used (Fig. 2). To more exactly locate the binding region, the $X$. fastidiosa lexA promoter was divided into four fragments (designated as LexA1, LexA2, LexA3 and LexA4) obtained by PCR amplification with the oligonucleotides listed in Table 2, DIG end-labelled and then used as probes in gel retardation assays (Fig. 3a). A stable

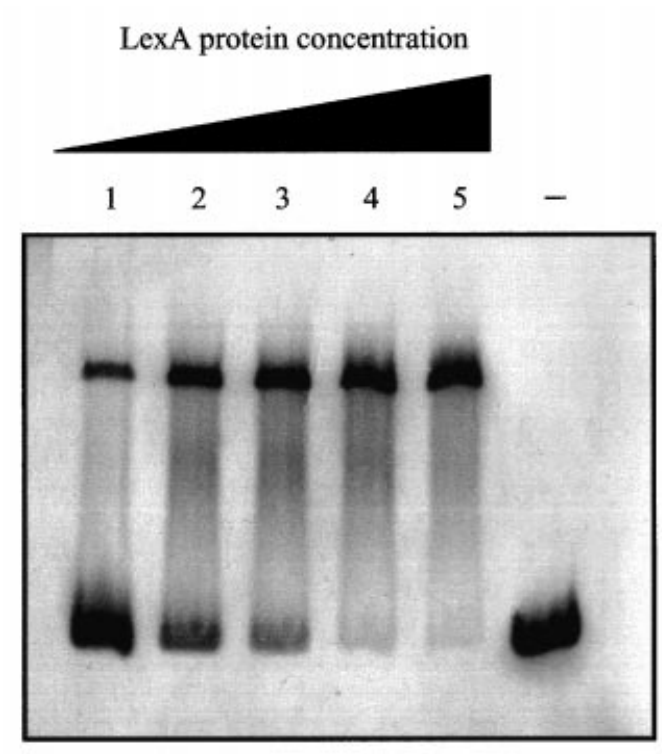

Fig. 2. Electrophoretic mobility of the DNA fragment containing the $X$. fastidiosa lexA promoter in presence of increasing concentrations of purified $X$. fastidiosa $\mathrm{His}_{6}-\mathrm{LexA}$ protein. In each binding reaction (end volume of $20 \mu \mathrm{l}$ ), amounts of purified $\mathrm{His}_{6}$-LexA protein used were $5 \mathrm{ng}$ (lane 1), $10 \mathrm{ng}$ (lane 2), $20 \mathrm{ng}$ (lane 3), $40 \mathrm{ng}$ (lane 4) and $80 \mathrm{ng}$ (lane 5). The mobility of the $X$. fastidiosa lexA promoter in the absence of purified $\mathrm{His}_{6}$-LexA protein is also shown as a control (-).

DNA-protein complex was observed when fragments LexA1, LexA2 and LexA3 were incubated in the presence of purified $X$. fastidiosa LexA, but there was no change in the mobility of the LexA4 fragment under the same conditions (Fig. 3b). These data indicate that the region to which the LexA protein binds, or at least a portion of it, must lie between positions -25 and -10 of the lexA promoter. No DNA-protein complex was detected when a $355 \mathrm{bp}$ fragment comprising $295 \mathrm{bp}$ of the upstream region of recA gene was used as a probe (Fig. $3 \mathrm{~b}$ ). This is in agreement with the close proximity existing between the X. fastidiosa lex $A$ and recA genes, which is only $184 \mathrm{bp}$ (Fig. 3a) and with the fact that both constitute a single transcriptional unit in this organism (Fig. 4) as shown by RT-PCR analysis of the $X$. fastidiosa RNA with RecAup and RecAdw primers beginning $111 \mathrm{bp}$ upstream and $60 \mathrm{bp}$ downstream of the translational stop and starting codons of the lex $A$ and $\operatorname{rec} A$ genes, respectively (Fig. $3 \mathrm{a}$ ). It is worth noting that this is the first bacterial species described so far in which lexA and recA genes constitute a single transcriptional unit.

The DNA-LexA complex was sensitive to competition by an excess of unlabelled LexA3 fragment, but not when non-specific DNA was used as competitor (Fig. 5a, lanes 3 and 4, respectively). The same DNA-LexA complex was obtained when, instead of purified LexA repressor, crude extracts from IPTG-induced E. coli BL21(DE3) cells overexpressing the X. fastidiosa LexA 
(a)

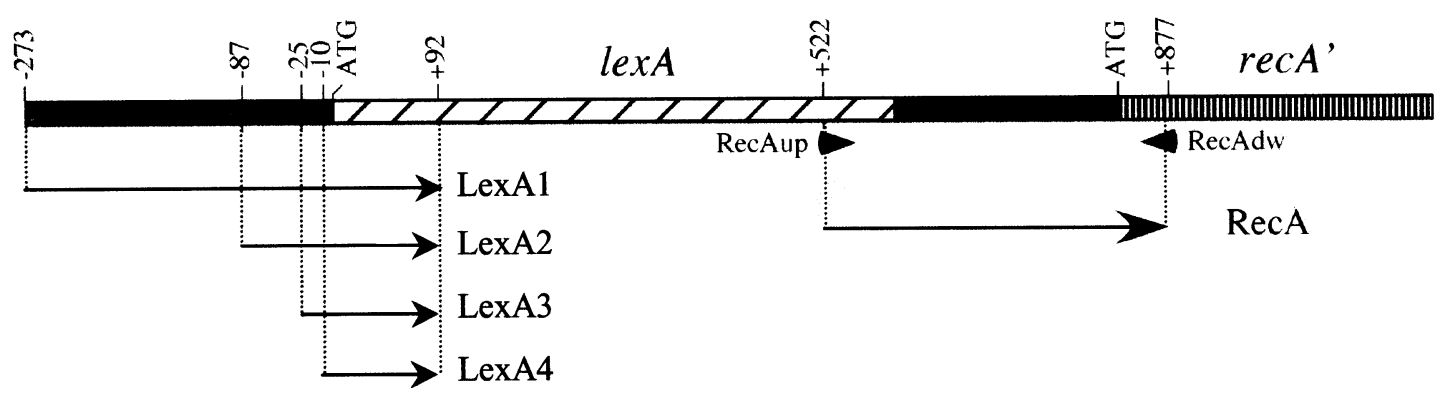

(b)
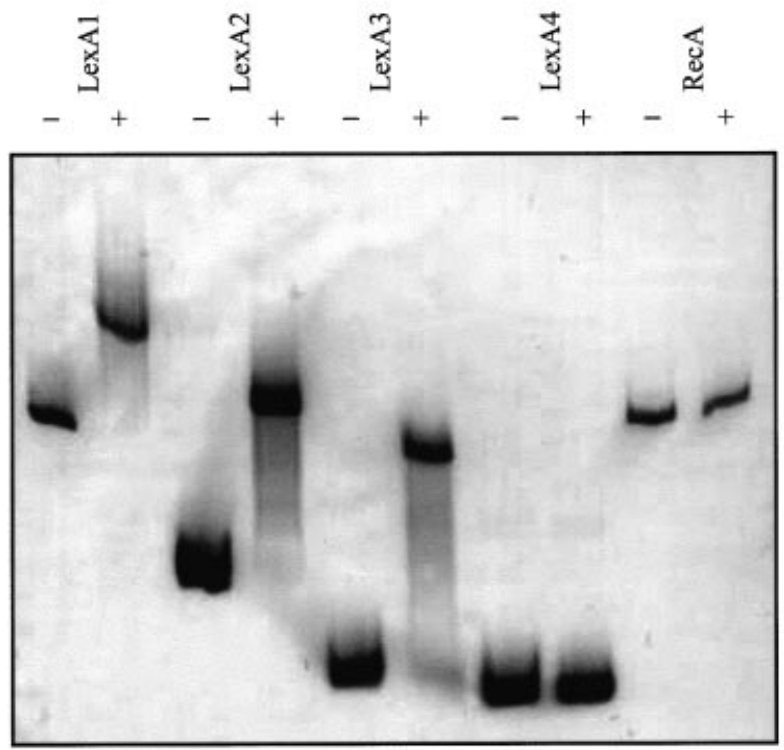

Fig. 3. (a) Diagram representing fragments amplified from the $X$. fastidiosa lexA-recA promoter used in gel retardation experiments. LexA1, LexA2, LexA3 and LexA4 fragments were generated by PCR amplification. The primers RecAup and RecAdw were used for amplification of the RecA DNA fragment and to analyse the transcriptional organization of the lex $A$ and recA genes. In all cases, positions indicated refer to the predicted translational starting point of the $X$. fastidiosa lexA gene (Simpson et al., 2000). (b) Electrophoretic mobility of LexA1, LexA2, LexA3, LexA4 and RecA fragments in the presence $(+)$ and in the absence $(-)$ of $40 \mathrm{ng}$ purified $X$. fastidiosa LexA protein.

(Fig. 1, lane 2) were used (Fig. 5a, lane 5). Moreover, no DNA-LexA complex was detected when crude extracts of E. coli BL21(DE3) cells carrying the pET15b plasmid alone were employed in gel retardation assays with the LexA3 fragment (Fig. 5a, lane 6). These results unequivocally demonstrate that the complex was indeed formed by the specific binding of the X. fastidiosa LexA protein to the lexA promoter.

\section{Mutational analysis of the lexA promoter}

A search for potential binding motifs (i.e. either direct or inverted repeats) in the sequence between positions -25 and the proposed ATG translational starting codon was carried out. The palindrome TTAGTAATAATACTAA, centred at the -11 position, was detected in the LexA3 fragment. Then, mutations were introduced into the left (TTAG $\rightarrow$ ACCA) and the right $(\mathrm{CTAA} \rightarrow \mathrm{AA}$ GG) halves of this palindrome, and their effects on the mobility of the LexA3 fragment were analysed.

Results obtained indicated that no DNA-LexA complex was formed when probes containing substitutions in either the left or right halves of the palindrome were employed (Fig. 5b, lanes 3 and 5). Furthermore, a threebase insertion between the TTAG and CTAA motifs also abolished the gel retardation of the band (Fig. $5 \mathrm{~b}$, lane 4).

To determine which bases of this TTAGN $_{8}$ CTAA palindrome were directly involved in the LexA interaction with the DNA, the effect of a single substitution in each one of the nucleotides of the palindrome and its immediately surrounding bases was tested. Results obtained indicated that a single nucleotide 


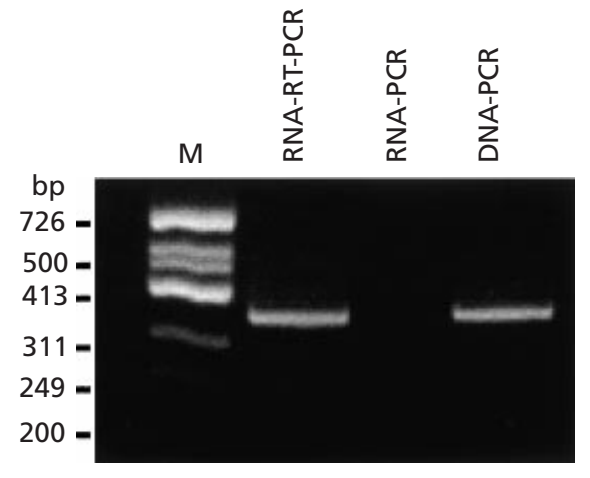

Fig. 4. RT-PCR analysis of transcripts of the lexA-recA operon in $X$. fastidiosa cells using RecAup and RecAdw primers in the presence of total RNA (RNA-RT-PCR). Results obtained when the PCR experiment is carried out with the same primers, but without reverse transcriptase, using either RNA (RNA-PCR) or DNA (DNA-PCR) are shown as controls. As indicated in Fig. 3a, the beginning of RecAup and RecAdw primers are $111 \mathrm{bp}$ upstream and $60 \mathrm{bp}$ downstream of the translational stop and starting codons of the lexA and recA genes, respectively. $M$, marker.

substitution in every position of the TTAG motif, as well as in any of the first three nucleotides (CTA) of the second motif of the palindrome, eliminates the DNALexA complex formation (Fig. 6). Additionally, mutagenesis of either T or A placed immediately upstream of the CTA trinucleotide also prevents DNA-LexA complex formation (Fig. 6). In accordance with these data, neither of the mutant fragments that do not form the DNA-LexA complex was able to abolish the mobility shift of the wild-type fragment originated in the presence of purified $X$. fastidiosa LexA protein when used in competition experiments (data not shown). These results demonstrate that binding of the $X$. fastidiosa LexA protein to the lexA promoter requires the TTA$\mathrm{GN}_{6}$ TACTA imperfect palindrome. In agreement with the fact that lexA and recA genes are co-transcribed (Fig. $3 \mathrm{~b}$ and Fig. 4), no motif presenting a sequence related with this TTAGN $_{6}$ TACTA palindrome is found immediately upstream of the $X$. fastidiosa recA gene.

It must be noted that the LexA binding site present upstream of the lexA-recA operon is very close to the translational start codon of the lexA gene. This is not a usual situation since LexA binding motifs of E. coli, Gram-positive bacteria and alpha Proteobacteria are typically located about $25 \mathrm{nt}$ upstream of their transcriptional starting points. However, some exceptions exist since Mycobacterium tuberculosis Rv3074 and Rv3776 genes also present a LexA binding sequence near their translational starting points (Davis et al., 2002).

\section{LexA protein binds different gene promoters in $X$. fastidiosa and $E$. coli}

As mentioned above, at least 40 genes are directly under the control of the LexA repressor in E. coli (Fernandez de Henestrosa et al., 2000; Courcelle et al., 2001). A
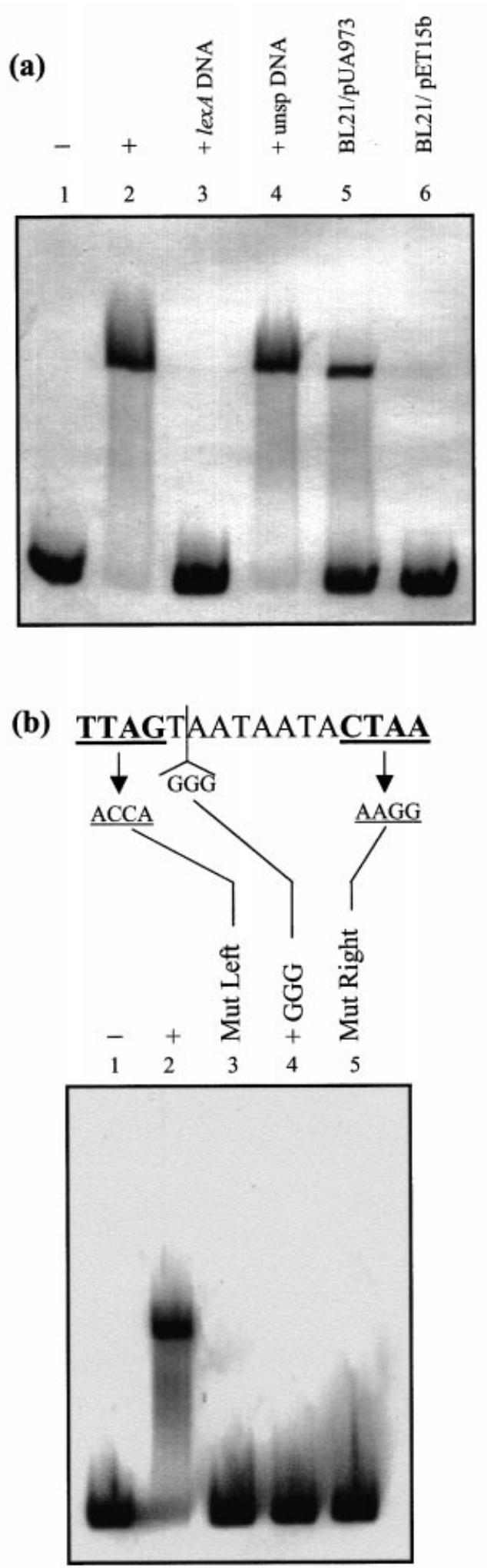

Fig. 5. (a) Effect of 300-fold molar unlabelled LexA1 fragment (lane 3) and pGEM-5Zf(+) plasmid DNA (lane 4) on the migration of the LexA3 fragment in the presence of $40 \mathrm{ng}$ purified $X$. fastidiosa LexA protein. The electrophoretic mobility of the LexA3 fragment in the presence of crude extracts from IPTG-induced $E$. coli BL21(DE3) cells carrying either the pUA973 plasmid or the pET15b vector alone is also shown as a control 


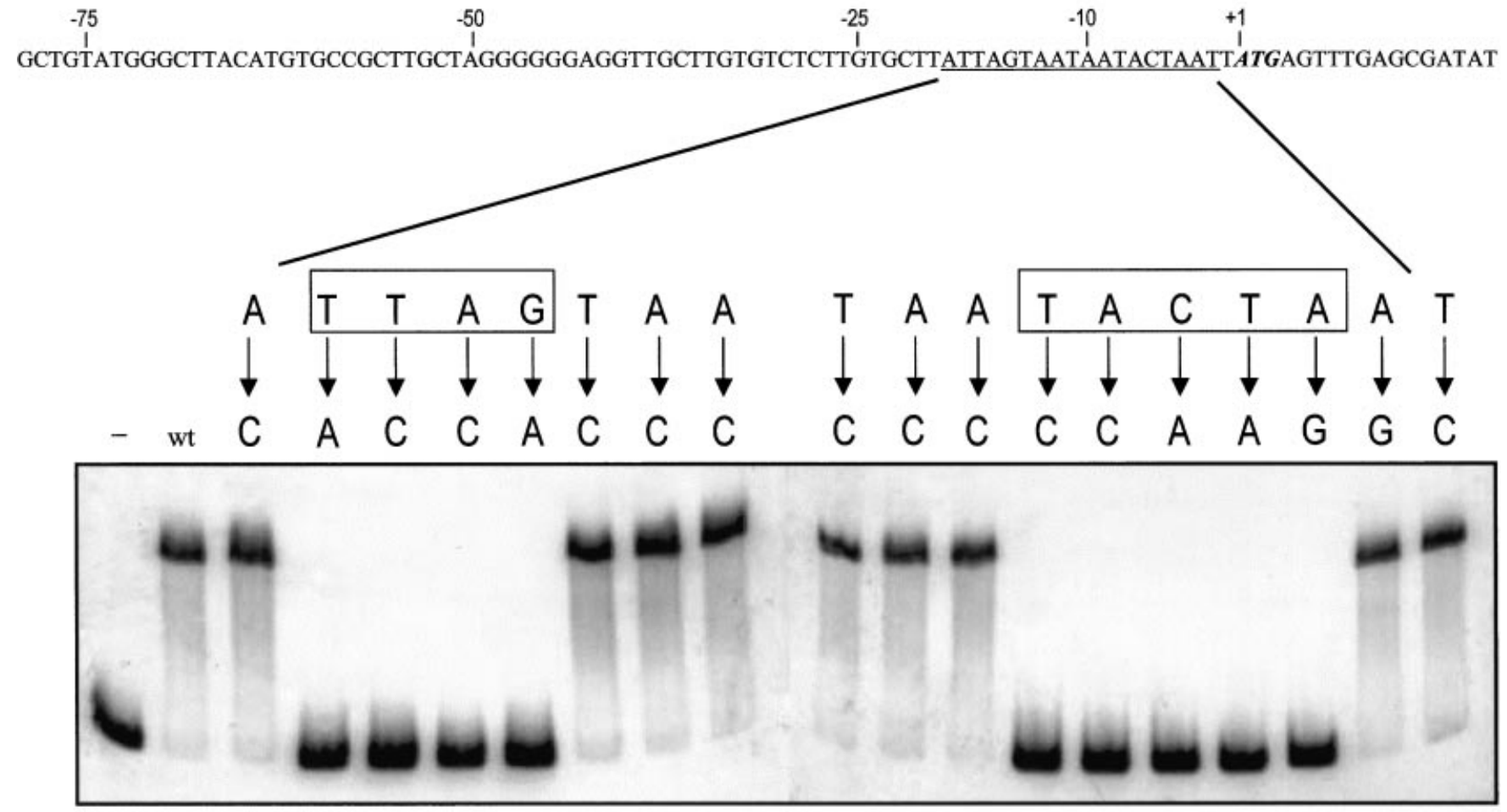

Fig. 6. Effect of single-nucleotide substitutions in the TTAG and CTAA motifs of the TTAGTAATAATACTAA palindrome as well as in its immediately surrounding bases in the electrophoretic mobility of the LexA3 fragment in the presence of $40 \mathrm{ng}$ purified $X$. fastidiosa LexA protein. The mobility of the wild-type LexA3 fragment in absence (-) or in presence (wt) of the same amount of purified $X$. fastidiosa LexA protein is also presented as a control. The proposed translational starting codon (position +1 ) of the $X$. fastidiosa lexA gene (Simpson et al., 2000) is in bold and italics and has been taken as the +1 position. Bases whose substitution abolish the LexA-DNA complex are boxed.

TBLASTX search using each one of the encoded products of these E. coli LexA-regulated genes as a query has enabled us to demonstrate that, besides lexA and $\operatorname{rec} A$, only eight of them $(u v r A, u v r B, \operatorname{ss} b, \operatorname{rec} N, \operatorname{ruv} A B, \operatorname{din} G$, ftsK and $y i g N)$ are present in the genome of $X$. fastidiosa. Sequence analysis of the upstream regions of these eight $X$. fastidiosa genes revealed that none has a sequence related to the TTAGN ${ }_{6}$ TACTA palindrome. In agreement with this fact, fragments containing $400 \mathrm{bp}$ of the upstream region of these eight genes were not able to inhibit the DNA-X. fastidiosa LexA complex formation when used as unlabelled competitors in gel retardation experiments with the DIG-labelled LexA3 fragment as a probe (data not shown). Moreover, a search in the X. fastidiosa genome database using the Findpatterns Program of the Genetics Computer Group

(lanes 5 and 6, respectively). (b) Electrophoretic mobility of mutant derivatives of the LexA3 fragment presenting substitutions in either the TTAG (Mut Left), CTAA (Mut Right) motif of the TTAGTAATAATACTAA palindrome or an insertion of $3 \mathrm{nt}(+\mathrm{GGG})$ in its internal region in the presence of $40 \mathrm{ng}$ purified $X$. fastidiosa LexA protein. In both panels, the mobility of the LexA3 fragment in the absence or in the presence of the same amount of purified $X$. fastidiosa LexA protein (lanes 1 and 2 , respectively) is also shown as control. package (Devereux et al., 1984) has revealed the presence of the TTAGN ${ }_{6}$ TACTA palindrome upstream of six ORFs: lexA-recA, XF1271, XF1417, XF1614, XF1823 and XF2313. It was further verified by competitive gel retardation assays (Fig. 7) that the LexA repressor only binds to the promoter of XF2313 encoding a putative DNA-modification methylase (Simpson et al., 2000). A similar case in which a putative LexA-binding sequence has been identified by in silico analysis, but which afterwards does not bind the LexA protein in vitro, has also been for the E. coli dinJ gene (Fernández de Henestrosa et al., 2000). The reasons for this lack of binding have not been established although they could be attributed to additional factors such as the structure of the region or the secondary role of the neighbouring bases of the regulatory sequence, as has been demonstrated for several transcriptional regulators (Winterling et al., 1998; Griffith \& Wolf, 2001; Davis et al., 2002). In agreement with this, the sequence between both motifs of the imperfect palindrome TTAGN ${ }_{6}$ TACTA is very different in XF1271, XF1417, XF1614 and XF1823 than in XF2313 and lexA (Fig. 7). It must be noted that in the $X$. fastidiosa genome there is another ORF (called XF2297) which is almost identical to XF2313 although it is slightly shorter probably due to a frameshift near its $\mathrm{N}$ terminus, suggesting that XF2297 derives from XF2313. 


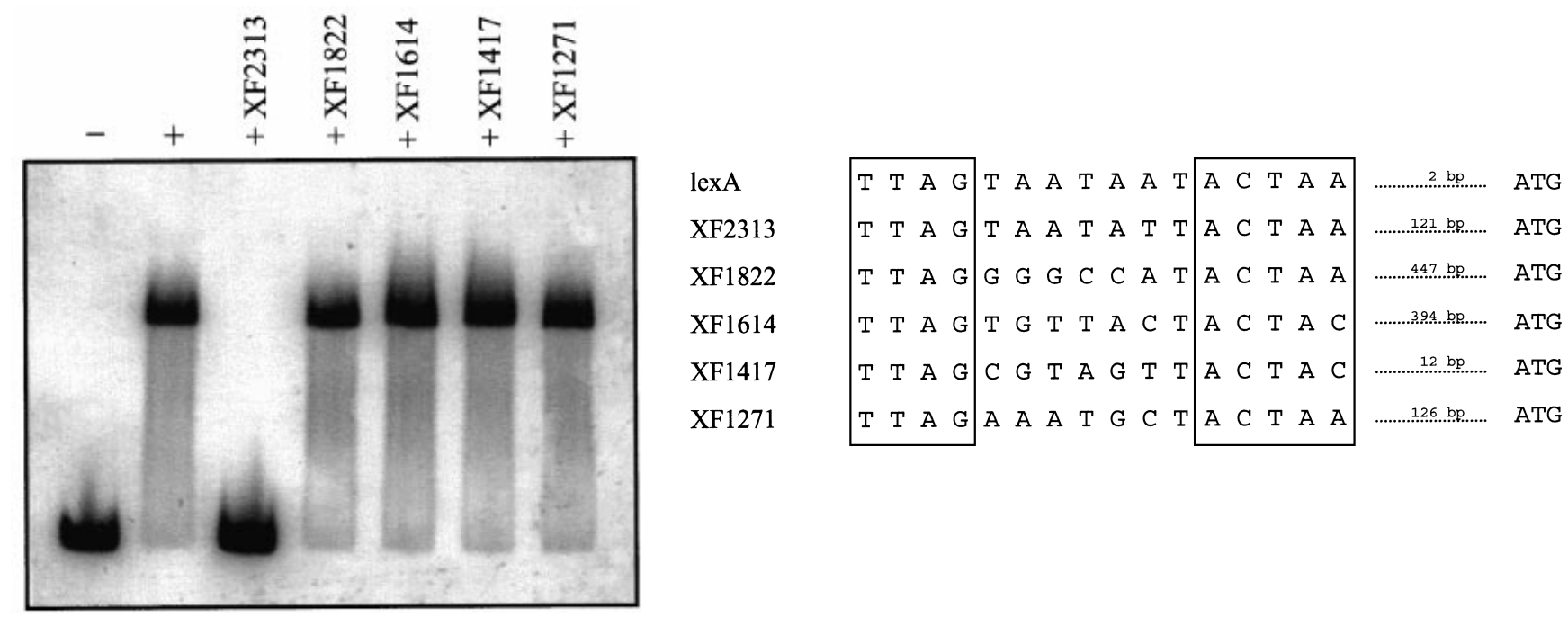

Fig. 7. Electrophoretic mobility of the LexA 3 fragment in the presence of purified $X$. fastidiosa LexA protein and $300-$ fold molar excess of unlabelled DNA fragments containing about 400 bp of the upstream region of XF2313, XF1822, XF1614, XF1417 and XF1271 genes of $X$. fastidiosa. The mobility of the LexA fragment in the absence of any additional DNA (+) or purified $X$. fastidiosa LexA protein $(-)$ is shown as a control. The sequence of the region between both palindromic halves (boxed) of the TTAGN 6 TACTA motif, as well as the distance to their respective translational starting codons, are also shown for each fragment to illustrate differences existing among them.

\begin{tabular}{|c|c|c|c|c|c|c|c|c|c|c|c|c|}
\hline Organism & Gene & & & & & & & que & nce & & & \\
\hline \multirow[t]{2}{*}{$X$. fastidiosa $\mathrm{CVC}$ strain } & $\operatorname{lex} A$ & TTA & $\mathbf{T} \mathbf{T} \mathbf{A}$ & & $\mathrm{T}$ & A & A & $\mathrm{T}$ & A & A & $\mathbf{T A C} \mathbf{T A}$ & ATTA \\
\hline & XF2313 & TAT & $\mathbf{T} \mathbf{T} \mathbf{A}$ & G & $\mathrm{T}$ & A & A & $\mathrm{T}$ & $\mathrm{T}$ & $\mathrm{T}$ & $\mathbf{T} \mathbf{A} \mathbf{C} \mathbf{T}$ & AATC \\
\hline \multirow[t]{2}{*}{$X$ fastidiosa oleander strain } & $\operatorname{lex} A$ & TTA & $\mathbf{T} \mathbf{T} A$ & G & $\mathrm{T}$ & A & A & $\mathrm{T}$ & A & A & T A C T A & ATTA \\
\hline & XF2313-like & TAT & $\mathbf{T} \mathbf{T} \mathrm{A}$ & G & $\mathrm{T}$ & A & A & A & A & $\mathrm{T}$ & $\mathbf{T} A \mathbf{C} \mathbf{T}$ & AATA \\
\hline \multirow[t]{2}{*}{$X$. fastidiosa almonder strain } & $\operatorname{lex} A$ & TTA & $\mathbf{T} \mathbf{T} \mathrm{A}$ & G & $\mathrm{T}$ & A & $\mathrm{A}$ & $\mathrm{T}$ & A & A & $\mathbf{T} A \mathbf{C} \mathbf{T}$ & ATTA \\
\hline & XF2313-like & TAT & T T A & $\mathbf{G}$ & $\mathrm{T}$ & $\mathrm{A}$ & A & $\mathrm{A}$ & A & $\mathrm{T}$ & T A C T A & AATA \\
\hline Xanthomonas citri & $\operatorname{lex} A$ & TCG & $\mathbf{T} \mathbf{T} A$ & G & $\mathrm{T}$ & A & G & $\mathrm{T}$ & A & A & $T A C T A$ & CTAA \\
\hline Xanthomonas campestris & $\operatorname{lex} A$ & TCG & $\mathbf{T} \mathbf{T} \mathrm{A}$ & G & $\mathrm{T}$ & A & G & $\mathrm{T}$ & $\mathrm{A}$ & A & T A C T A & CTAA \\
\hline Xanthomonas oryzae & $\operatorname{lex} A$ & TTA & T T A & G & $\mathrm{T}$ & A & $\mathrm{A}$ & $\mathrm{T}$ & A & A & TA $A$ C $T$ A & AACA \\
\hline Consensus sequence & & & T T A & $\mathbf{G}$ & $\mathrm{T}$ & A & $\mathrm{R}$ & W & A & $\mathrm{W}$ & T A C T A & \\
\hline
\end{tabular}

Fig. 8. Alignment of the sequence containing the TTAGN ${ }_{6}$ TACTA motif present upstream of several genes of members of the Xanthomonas and Xylella genera. The consensus sequence includes nucleotides conserved in more than the $20 \%$ of 9 sequences considered. The GenBank accession numbers of Xanthomonas citri, Xan. campestris and Xan. oryzae lexA genes are AF081945, AF399933 and AF399932, respectively. The upstream sequences of XF2313-like genes of Xyl. fastidiosa pv. oleander and $\mathrm{XYl}$. fastidiosa pv. almonder strains were obtained by TBLASTN analysis against their respective genomes (http://igweb.integratedgenomics.com/GOLD/prokaryagenomes.html) using the Xyl. fastidiosa XF2313 gene as a query. In agreement with the standard nomenclature $\mathrm{R}$ is $\mathrm{A}$ or $\mathrm{G}$ and $\mathrm{W}$ is $\mathrm{A}$ or $\mathrm{T}$.

Nevertheless, a $600 \mathrm{bp}$ fragment containing the upstream region of XF2297 neither presents a copy of the TTAGN ${ }_{6}$ TACTA motif nor binds the $X$. fastidiosa LexA protein (data not shown). The LexA-binding sequence was perhaps lost in the genetic rearrangement that produced XF2297 from XF2313.
Three proteins with a significant degree of identity (about $43 \%$ ) to the putative $X$. fastidiosa DNAmodification methylase encoded by XF2313 have been detected in the Streptomyces coelicolor genome after a TBLASTX search in the GenBank database. However, upstream of these $S$. coelicolor genes a Gram-positive 
LexA-binding sequence is not found, suggesting that the presence of a LexA-binding sequence upstream of orthologous genes encoding an XF2313-like protein is not a general phenomenon. The absence of a LexA box in the promoters of E. coli LexA-regulated orthologous genes has also been described for Ps. aeruginosa (uvrA and $u v r B)$ and $M$. tuberculosis $(u v r A, \operatorname{recN}, \operatorname{din} P$ and $\operatorname{din} G)$ (Rivera et al., 1996, 1997; Brooks et al., 2001).

Moreover, the TTAGN $_{6}$ TACTA palindrome is also present in an upstream region $169 \mathrm{nt}$ long in the Xanthomonas campestris lexA gene, in which it has been shown that its own LexA protein binds, although the precise binding sequence has not been established (Yang et al., 2001). It must be noted that Xyl. fastidiosa and Xan. campestris LexA proteins present a high degree of identity in their $\mathrm{N}$-terminal regions. According to this fact, the DNA binding sequence of both bacteria are expected to be very similar. Furthermore, the fact that the TTAGN ${ }_{6}$ TACTA palindrome is perfectly conserved in the lexA promoters of Xanthomonas oryzae, Xyl. fastidiosa pv. oleander and Xyl. fastidiosa pv. almonder, as well as in the promoter of the XF2313like genes of these two former species (Fig. 8), leads us to propose this sequence as the LexA binding site of the Order Xanthomonadales. The TTAGN ${ }_{6}$ TACTA palindrome is the first LexA-binding sequence different from the E. coli-like one identified in the gamma subclass Proteobacteria.

\section{$X$. fastidiosa lexA-recA and XF2313 transcriptional units are inducible by DNA damage}

To further characterize the behaviour of $X$. fastidiosa genes binding to LexA protein, the effect of mitomycin $\mathrm{C}$ $\left(20 \mu \mathrm{g} \mathrm{ml}^{-1}\right)$ on the expression of lexA-recA and XF2313 was analysed. Table 3 indicates that both transcriptional units are induced by DNA damage, whereas expression of two non-DNA-damage-related genes (those encoding tryptophan and threonine synthase) is not significantly stimulated by mitomycin C. It is worth noting that all LexA-regulated E. coli genes which are also present in $X$. fastidiosa, with the exception of $s s b$, are also DNA damage-inducible in this organism despite the fact they cannot bind to their own LexA protein (Table 3). A similar result has also been described for M. tuberculosis in which $u v r A$ and $u v r B$ are DNA damage-inducible but do not bind the LexA protein, whereas $\operatorname{rec} N$, $\operatorname{din} P$ and $\operatorname{din} G$ have their transcriptions neither stimulated by DNA injuries nor bind LexA (Brooks et al., 2001). The DNA damage-mediated transcription of genes that do not bind LexA protein in either M. tuberculosis or X. fastidiosa could be explained by two different mechanisms: i) the existence of a lexA-independent pathway of induction, or ii) the presence of an additional transcriptional regulatory factor which is under LexA control. Nevertheless, this last possibility seems to be unlikely since a gene encoding a putative transcriptional regulator, aside from lexA, presenting its own LexA-binding sequence has not been detected in either the $M$. tuberculosis or X. fastidiosa genomes, (Simpson et al.,
Table 3. Mitomycin C-mediated induction of genes whose promoters bind either the $X$. fastidiosa or E. coli LexA proteins

\begin{tabular}{|lcc|}
\hline Gene & $\begin{array}{c}\text { X. fastidiosa } \text { LexA } \\
\text { binding }\end{array}$ & $\begin{array}{c}\text { Induction } \\
\text { factor" }^{*}\end{array}$ \\
\hline lexA & + & $3 \cdot 91$ \\
XF2313 & + & $15 \cdot 98$ \\
ssb & - & $1 \cdot 36$ \\
uvrA & - & $2 \cdot 27$ \\
uvrB & - & $6 \cdot 11$ \\
fts $K$ & - & $4 \cdot 3$ \\
$\operatorname{recN}$ & - & $6 \cdot 4$ \\
yigN & - & $6 \cdot 52$ \\
ruvAB & - & $6 \cdot 67$ \\
$\operatorname{din} G$ & - & $7 \cdot 27$ \\
XF1375† & - & $1 \cdot 27$ \\
XF2223† & - & $1 \cdot 66$ \\
\hline
\end{tabular}

* The induction factor is the ratio of mRNA concentration of each gene of cells treated with mitomycin $\mathrm{C}$ to that of untreated cells. Values were calculated $16 \mathrm{~h}$ after addition of mitomycin C. For all cases, data presented are the means of three independent experiments (each in triplicate), and the single standard deviation of any value was never greater than $10 \%$.

†XF1375 and XF2223 genes of X. fastidiosa encoding tryptophan synthase and threonine synthase, respectively, were used as negative controls.

2000; Cole et al., 1998). Additional investigations are necessary to better understand the molecular basis of this behaviour. Moreover, the fact that bacterial species belonging to phylogenetic groups as different as Grampositive and the gamma subclass of Proteobacteria have DNA damage-inducible genes which are unable to bind the LexA repressor suggests that this phenomenon may be widespread in the bacterial world.

The presented results clearly indicate that gene composition of the LexA network can have significant variations depending on the bacterial species. The reasons for these differences are not yet known, but, besides evolutionary divergences, they could probably be related to the specific ecological and physiological niches of each bacterial group. Nevertheless, at the moment there is not enough information to precisely establish this relationship. Further work is needed to identify new LexA-binding sequences in other bacterial phylogenetic groups to be able to determine the gene composition of their corresponding LexA regulons for the understanding of the variability of this important gene network.

\section{ACKNOWLEDGEMENTS}

This work was funded by Grants BMC2001-2065 from the Ministerio de Ciencia y Tecnología (MCyT) de España and 2001SGR-206 from the Departament d'Universitats, Recerca i Societat de la Informació (DURSI) de la Generalitat de 
Catalunya. Antonio R. Fernández de Henestrosa and Gerard Mazón were recipients of a postdoctoral contract and a predoctoral fellowship from the MCyT, respectively. We are deeply indebted to Dr Roger Woodgate for his generous gifts. We wish to acknowledge Joan Ruiz, Susana Escribano, Pilar Cortés, Rene R. Palma and Anelise G. Mariano for their excellent technical assistance and collaboration and to our English-teaching university colleague, Mr Chuck Simmons, for his help in the language revision and correction of this article.

\section{REFERENCES}

Bertrand-Burggraf, E., Hurstel, S., Daune, M. \& Schnarr, M. (1987). Promoter properties and negative regulation of the uvrA gene by the LexA repressor and its amino-terminal binding domain. J Mol Biol 193, 293-302.

Bradford, M. M. (1976). A rapid and sensitive method for the quantification of microgram quantities of protein utilizing the principle of protein-dye binding. Anal Biochem 72, 248-254.

Brent, R. \& Ptashne, M. (1981). Mechanism of action of the lexA gene product. Proc Natl Acad Sci US A 78, 4204-4208.

Brooks, P. C., Movahedzadeh, F. \& Davis, E. O. (2001). Identification of some DNA damage-inducible genes of Mycobacterium tuberculosis: apparent lack of correlation with LexA binding. J Bacteriol 183, 4459-4467.

Cole, S. T., Brosch, R., Parkhill, J. \& 36 other authors. (1998). Deciphering the biology of Mycobacterium tuberculosis from the complete genome sequence. Nature 393, 537-544.

Courcelle, J., Khodursky, A., Peter, B., Brown, P. O. \& Hanawalt, P. C. (2001). Comparative gene expression profiles following UV exposure in wild-type and SOS-deficient Escherichia coli. Genetics 158, 41-64.

Davis, J. M., French, W. J. \& Schaad, N. (1981). Axenic culture of the bacteria associated with phony disease of peach and plum leaf scald. Curr Microbiol 6, 309-314.

Davis, E. O., Dullaghan, E. M. \& Rand, L. (2002). Definition of the Mycobacterial SOS box and use to identify LexA-regulated genes in Mycobacterium tuberculosis. J Bacteriol 184, 3287-3295.

Devereux, J., Haeberli, P. \& Smithies, O. (1984). A comprehensive set of sequence analysis programs for the VAX. Nucleic Acids Res 12, 387-395.

Eisen, J. A. \& Hanawalt, P. C. (1999). A phylogenomic study of DNA repair genes, proteins, and processes. Mutat Res 435, 171-213.

Fernandez de Henestrosa, A. R., Rivera, E., Tapias, A. \& Barbé, J. (1998). Identification of the Rhodobacter sphaeroides SOS box. Mol Microbiol 28, 991-1003.

Fernandez de Henestrosa, A. R., Ogi, T., Aoyagi, S., Chafin, D., Hayes, J. J., Ohmori, H. \& Woodgate, R. (2000). Identification of additional genes belonging to the LexA regulon in Escherichia coli. Mol Microbiol 35, 1560-1572.

Griffith, K. L. \& Wolf, R. E. (2001). Systematic mutagenesis of the DNA binding sites for SoxS in the Escherichia coli zwf and $f p r$ promoters: identifying nucleotides required for DNA binding and transcription activation. Mol Microbiol 40, 1141-1154.

Khil, P. P. \& Camerini-Otero, R. D. (2002). Over 1000 genes are involved in the DNA damage response of Escherichia coli. Mol Microbiol 44, 89-105.

Laemmli, U. K. (1970). Cleavage of structural proteins during the assembly of the head of bacteriophage T4. Nature 227, 680-685. Little, J.W. (1991). Mechanism of specific LexA cleavage: autodigestion and the role of RecA coprotease. Biochimie 73, 411-422.

Little, J. W., Mount, D. \& Yanisch-Perron, C. R. (1981). Purified LexA protein is a repressor of the recA and lexA genes. Proc Natl Acad Sci US A 78, 4199-4203.

Luo, Y., Pfuetzner, R. A., Mosimann, S., Paetzel, M., Frey, E. A., Cherney, M., Kim, B., Little, J. W. \& Strynadka, C. J. (2001). Crystal structure of LexA : a conformational switch for regulation of self-cleavage. Cell 106, 585-594.

Makarova, K. S., Mironov, A. A. \& Gelfand, M. S. (2001). Conservation of the binding site for the arginine repressor in all bacterial lineages. Genome Biol 2, 131-138.

Monteiro, P. B., Teixeira, D. C., Palma, R. R., Garnier, M., Bové, J. M. \& Renaudin, J. (2001). Stable transformation of the Xylella fastidiosa citrus variegated chlorosis strain with oriC plasmids. Appl Environ Microbiol 67, 2263-2269.

Panina, E. M., Mironov, A. A. \& Gelfand, M. S. (2001). Comparative analysis of Fur regulons in Gamma-proteobacteria. Nucleic Acids Res 29, 5195-5206.

Rivera, E., Vila, L. \& Barbé, J. (1996). The $u v r B$ gene of Pseudomonas aeruginosa is not DNA damage inducible. J Bacteriol 178, 5550-5554.

Rivera, E., Vila, L. \& Barbé, J. (1997). Expression of the Pseudomonas aeruginosa uvrA gene is constitutive. Mutat Res 377, 149-155.

Rodionov, D. A., Mironov, A. M. \& Gelfand, M. S. (2001). Transcriptional regulation of pentose utilisation systems in the Bacillus/Clostridium group of bacteria. FEMS Microbiol Lett 205, 305-314.

Roy, S., Sahu, A. \& Adhya, S. (2002). Evolution of DNA binding motifs and operators. Gene 285, 169-173.

Sambrook, J., Fritsch, E. F. \& Maniatis, T. (1992). Molecular Cloning. A Laboratory Manual, 2nd edn. Cold Spring Harbor, NY : Cold Spring Harbor Laboratory.

Sanger, F., Nicklen, S. \& Coulson, S. (1977). DNA sequencing with chain-terminating inhibitors. Proc Natl Acad Sci USA 74, 5463-5467.

Sassanfar, M. \& Roberts, J. W. (1990). Nature of SOS-inducing signal in Escherichia coli: the involvement of DNA replication. J Mol Biol 212, 79-96.

Silhavy, T. J., Berman, M. L. \& Enquist, L. W. (1984). Experiments With Gene Fusions. Cold Spring Harbor, NY: Cold Spring Harbor Laboratory.

Simpson, A. J. G., Reinach, F. C., Arruda, P. \& 113 other authors (2000). The genome sequence of the plant pathogen Xylella fastidiosa. Nature 406, 151-159.

Tan, K., Moreno-Hagelsieb, G., Collado-Vives, J. \& Stormo, G. D. (2001). A comparative genomics approach to prediction of new members of regulons. Genome Res 11, 566-584.

Tapias, A. \& Barbé, J. (1999). Regulation of divergent transcription from the uvrA-ssb promoters in Sinorhizobium meliloti. Mol Gen Genet 262, 121-130.

Tapias, A., Fernández, S., Alonso, J. C. \& Barbé, J. (2002). Rhodobacter sphaeroides LexA has dual activity: optimising and repressing recA gene transcription. Nucleic Acids Res 30, 1539-1546.

Voloshin, O. N., Ramirez, B. E., Bax, A. \& Camerini-Otero, R. D. (2001). A model for the abrogation of the SOS response by an SOS protein: a negatively charged helix in DinI mimics DNA in its interaction with RecA. Genes Dev 15, 415-427.

Walker, G. C. (1984). Mutagenesis and inducible responses to 
deoxyribonucleic acid damage in Escherichia coli. Microbiol Rev 48, 60-93.

Winterling, K. W., Chafin, D., Hayes, J. J., Sun, J., Levine, A. S. Yasbin, R. E. \& Woodgate, R. (1998). The Bacillus subtilis DinR binding site: redefinition of the consensus sequence. J Bacteriol 180, 2201-2211.
Yang, Y. C., Yang, M. K., Kuo, T. T. \& Tu, J. (2001). Structural and functional characterization of the lexA gene of Xanthomonas campestris pathovar citri. Mol Gen Genet 265, 316-326.

Received 4 June 2002; accepted 26 July 2002. 